\title{
The effect of work motivation on performance with job satisfaction as an intervening variable in the Faculty of Islamic Economics and Business, UIN Walisongo Semarang
}

\author{
Nurudin ${ }^{1}$ \\ ${ }^{1}$ Faculty of Islamic Economics and Business, UIN Walisongo Semarang, Indonesia
}

\begin{abstract}
Purpose - This study aims to determine the effect of work motivation on performance with job satisfaction as an intervening variable.

Method - The population in this study were all employees at the Faculty of Islamic Economics and Business UIN Walisongo Semarang with a total sample of 58 respondents. The analysis in this study uses path analysis technique.

Result - The results showed that work motivation had a significant effect on job satisfaction, work motivation had a significant effect on performance and job satisfaction variables had a significant effect on performance. The results of the path analysis conducted showed that work motivation had a direct effect on employee performance, while work motivation had an indirect effect on performance through intervening work.
\end{abstract}

Implication - This study assists the management of higher education to create working design for a better performance.

Originality - This study enriches the empirical study of job performance in higher education context in Indonesia.

Keywords: performance, job satisfaction, work motivation 


\section{Introduction}

Faculty of Islamic Economics and Business (FEBI) UIN Walisongo Semarang was founded on December 13, 2013. Until now, the faculty has four study programs, namely: 1. Islamic

JIEMB | 32 Economics Study Program, 2. Sharia Banking Study Program (D3), 3. Islamic Banking Study Program (S1), 4. Sharia Accounting Study Program.

The interesting thing to observe from the conditions after the establishment of FEBI is the development of good performance. The performance of these agencies is inseparable from the performance of all existing employees. Employee performance is very important because a decrease in the performance of both individuals and groups in an agency can have a significant impact on the agency. According to Mangkunegara (2001), performance can be defined as the quality and quantity of work that can be achieved by an employee in carrying out a task in accordance with the responsibilities assigned to him. If the performance of human resources is good, then the goals, vision and mission of the organization will also be good, and vice versa. One of the important factors that influences employee performance is motivation. Mangkunegara (2001) states that the factors that influence performance are ability factors and motivation factors. These are supported by the effectiveness and efficiency of employees so that employee motivation can be maintained and even increased. Conversely, if employee motivation decreases, it will have a negative impact on the company. Apart from motivation factors, employee performance is also influenced by job satisfaction. Obtaining employees job satisfaction either by providing appropriate wages, providing jobs in accordance with their expertise, or establishing good relationships with superiors will improve the performance of employees. A high standard of job satisfaction will make performance increase and vice versa; if the employee gets lower or not as expected, it will cause the employee to be dissatisfied so that the performance will decrease.

Today there is a decline in the performance of the Faculty of Islamic Economics and Business with the absence of the Quality Assurance Awards held by the Quality Assurance Institute of UIN Walisongo Semarang. The QA Award is an award given to faculties with the best academic quality achievements at UIN Walisongo. This 
Table 1. List of awardees of Quality Assurance Awards UIN Walisongo Semarang

\begin{tabular}{lll}
\hline No & Year & Faculty \\
\hline 1. & 2015 & Faculty of Economics and Islamic Business \\
2. & 2016 & Faculty of Economics and Islamic Business \\
3. & 2017 & Postgraduate Program \\
4. & 2018 & Faculty of Tarbiyah and Teacher Training \\
5. & 2019 & Faculty of Science and Technology \\
\hline
\end{tabular}

award is measured from the results of academic monitoring and evaluation, the results of internal academic quality audits, the results of online student evaluations of lecturer performance and the average teaching attendance of lecturers. Data for 5 consecutive years (2015-2019) can be seen in Table 1.

From Table 1, it is concluded that in 2015 and 2016 the Faculty of Islamic Economics and Business won Quality Assurance Awards, in 2017 Quality Assurance Awards were won by Postgraduate Program, in 2018 the Quality Asurance Awards were won by the Faculty of Tarbiyah and Teacher Training, and in 2019 the Quality Assurance Awards were won by the Faculty of Science and Technology. This shows a decline in the performance of the Faculty of Islamic Economics and Business in 2017-2019.

Research conducted by Listianto and Setiaji (2007) states that work motivation has a positive and significant effect on employee performance. In addition, research conducted by Prasetyo and Wahyuddin (2003) supports previous research which states that motivation has a positive and significant effect on employee performance. From the previous research, the relationship between motivation and performance is directly proportional, meaning that the higher the employee motivation to work, the higher the resulting performance is. The high performance is also strengthened by the dimension of job satisfaction.

According to Kreitner and Kinicki (2005), job satisfaction is an effectiveness or emotional response to various aspects of work. Job satisfaction is very necessary and important for the organization because every employee who is satisfied is expected to be able to work at full capacity, so that it will improve the organizational performance. Conversely, if employees are not satisfied with their performance, there will be a condition of declining performance. 
The problem statement in this study is based on a research gap on previous research which shows different results and the gap phenomenon that the average number of absent employees was quite high, that was $15.49 \%$ per month. This means that it can result in obstruction of work completion and a decrease in performance. In addition, in 2017, the Faculty of Economics and Islamic Business did not win the Quality Assurance Awards from Quality Assurance Bureau (LPM) of UIN Walisongo Semarang. This shows a decline in performance at the Faculty of Islamic Economics and Business. To further examine the matters that affect performance, the research problem examined in this study is how to improve and maintain performance at the Faculty of Islamic Economics and Business UIN Walisongo Semarang to be always good and increasing. Based on these problems, the research questions can be derived as follows:

1. Does work motivation affect employee satisfaction in Faculty of Islamic Economics and Business UIN Walisongo Semarang?

2. Does job satisfaction affect the employee performance in Faculty of Islamic Economics and Business UIN Walisongo Semarang?

3. Does work motivation affect the employee performance in Faculty of Islamic Economics and Business UIN Walisongo Semarang?

\section{Literature Review}

\section{Employee Performance}

Mangkunegara in Brahmasari (2008) defines performance as the quality and quantity of work that can be achieved by an employee in carrying out tasks in accordance with the responsibilities assigned to him. According to Soeprihantono in Koesmono (2005), performance is the result of an employee's work during a certain period compared to various possibilities, for example standards, targets that have been determined in advance and have been mutually agreed upon.

The factors that affect performance are: first, effectiveness and efficiency. According to Prawirosentono in Listianto (2007), if a certain goal can finally be achieved, we may say that the activity is effective. But if the consequences that the activity is not looking for have an important value from the results achieved, resulting in 
dissatisfaction even though it is effective, it is called inefficient. Second, authority. The meaning of authority according to Barnard in Listianto (2007) is the nature of a communication or order in a formal organization that is owned (received) by a member of the organization to other members to carry out a work activity in accordance with its contribution (labor contribution). The order states what can be done and cannot be done in the organization. Third, discipline. According to Prawirosentono in Listianto (2007), discipline is obeying applicable laws and regulations. So, employee discipline is the activity of the employee in respecting the work agreement with the organization where he works. Fourth, initiative, which relates to thinking and creativity in the form of ideas to plan something related to organizational goals. Thus, initiative is the driving force for progress aimed at influencing organizational performance.

Performance appraisal plays a very important role in increasing motivation in the workplace. Employees want and need feedback on their performance, and assessments provide an opportunity to provide feedback to them. If performance is not up to standard, then the appraisal provides an opportunity to review the employee's progress and to develop a performance improvement plan. Performance appraisal is an attempt to compare the employee's actual performance with the work performance expected from him (Dessler, 2000).

Performance appraisal is an important part of the human resource development process, both for the company and for employees. For an organization or company, the results of employee appraisals are important for their meaning and role in decision making in the employee development process, while for the employee concerned, the assessment acts as feedback on the abilities, weaknesses and potential of the employee. Who plays an important role in an organization depends on the performance of its employees. In order for employees to work as expected, an employee must be motivated to work to achieve everything he wants. If the morale becomes high, all the work assigned to him will be completed more quickly and precisely. A job that is done quickly and precisely is a good work achievement (Listianto, 2007). 


\section{Work Motivation}

A person who is not motivated only gives a minimum effort in terms of work. The concept of motivation is an important concept in the study of individual performance. Thus motivation means giving motivation, arising motivation or things that give rise to encouragement or conditions that give rise to encouragement. It can also be said that motivation is the factor that drives people to act in a certain way.

Motivation is an activity that causes, channels and maintains human behavior. This motivation is an important subject for managers because managers must work with and through other people. Managers need to understand people who have certain behaviors in order to influence them to work in accordance with what the organization wants (Hadoko, 2002). In addition, Robbins (2006) suggests that motivation is the desire to do as a willingness to spend a high level of effort for organizational goals, which is conditioned by the ability of that effort to meet an individual need.

Hughes et al. in Koesmono (2005) say that generally within a worker there are two important things, namely compensation and expectation. Compensation is a reward from an employer to an employee who has always contributed as a measure of whether a person is satisfied or not in carrying out their duties or work, while expectations are the expectations that will be obtained in carrying out their activities so that they can spur someone to move forward.

Herzberg in Robbins (2006) introduced the hygiene motivation theory or what is often referred to as the two-factor theory, which argues that an individual's relationship with his job is a basic relationship and that a person's attitude towards work will determine the success or failure of the individual. Herzberg also states that there are factors that someone wants from their work. From the categorized responses, it is known that the responses of those who feel happy are different from the responses of those who do not feel happy.

\section{Job Satisfaction}

Satisfaction is a person's attitude towards work as the difference between the amount of reward received by workers and the amount that is believed to be received (Alwiyah, 2016). Job satisfaction is a general attitude of an employee towards his job. Job satisfaction shows a match between someone's expectations that 
arise with the rewards that the job provides (Robbins, 2006). Employee satisfaction or dissatisfaction depends on the difference between what is expected. If what the employee gets is lower than expected, it will cause the employee to be dissatisfied. Factors that affect job satisfaction or dissatisfaction are: type of job, co-workers, benefits, fair treatment, job security, opportunities to contribute ideas, salary, and opportunities to develop.

Mangkunegara in Brahmasari (2008) argues that job satisfaction is related to variables such as turnover, absentee level, age, job level, and company organization size. Job satisfaction related to turnover means that high job satisfaction is always associated with low employee turnover, and conversely, if many employees are dissatisfied, then employee turnover is high.

Job satisfaction is related to the level of absenteeism (attendance) which means that employees who are less satisfied tend to have high levels of absence. Job satisfaction related to age means that employees who tend to be older will feel more satisfied than employees who are relatively younger. It is assumed that older employees are more experienced in adapting to the work environment, and employees with younger ages usually have ideal expectations about the world of work, so that if there is a gap or imbalance between their expectations and work realities it can cause them to be dissatisfied.

Job satisfaction associated with job level means that employees who occupy higher levels of work tend to be more satisfied than employees who occupy lower jobs, because employees with higher levels of work show good work abilities and are active in expressing ideas and being creative at work. In addition, job satisfaction is related to the size of the company organization. It means that the size of the company can affect the communication, coordination, and employee participation processes so that it can affect employee job satisfaction.

Luthans in Listianto (2007) formulates job satisfaction as a positive or pleasant emotional state of a person that is produced and as an assessment of a job or work experience. Job satisfaction reflects a person's feelings about his job. This can be seen in the positive attitude of employees towards work and everything they face in their work environment. Each employee has a different level of satisfaction according to the values that apply to him. The more 
aspects of work that are in accordance with the wishes and aspects of the individual, the higher the level of job satisfaction is. Job satisfaction can affect the turnover rate and the absentee level on the physical and mental health of employees.

Furthermore, Mangkunegara in Brahmasari (2008) argues that there are two factors that influence job satisfaction, namely factors that exist in employees and factors of work. The factors that exist in employees are intelligence (IQ), special skills, age, gender, physical condition, education, work experience, years of service, personality, emotions, ways of thinking, perceptions, and work attitudes. Meanwhile, occupational factors are the type of work, organizational structure, rank (class), position, quality of supervision, financial security, opportunities for promotion, social interactions, and work relations.

The theory of job satisfaction according to Wesley and Yulk (in Purwanto, 2007) can be explained according to three kinds of theories, namely:

Discrepancy theory suggests that to measure one's job satisfaction is by calculating the difference between what should be and what is felt. Then, Locke (1970) explained that job satisfaction depends on the discrepancy between should be (expectations, needs or values) and what he feels or perceptions have been obtained or achieved through work. Thus, people will feel satisfied if there is no difference between what they want and their perception of reality because the desired minimum limit has been met. According to research conducted by Wanous and Lawler, it is suggested that employees' attitudes toward their work depend on how discrepancies are perceived.

Equity theory was developed by Adam (1963). In principle, this theory suggests that people will feel satisfied as long as they feel there is justice (equity). The feeling of equity and inequity for a situation is obtained by people by comparing themselves with other people in the same class, at work, or elsewhere. This theory identifies the elements of equity covering three things, namely:

1. Input, is something valuable that is felt by employees as input to their work;

2. Outcomes, is anything valuable that is felt as a result of their work; 
3. Personal comparisons, is the comparison between the input and outcomes that they get.

Two-factor theory was put forward by Herzberg (2017). Based on his research, Herzberg split situations that affect one's attitude toward his job into two groups:

1. Statisfers or motivators-factors or situations that prove a source of satisfaction consisting of: achievement, recognition, work itself, responsibility and advancement;

2. Dissatifiers or hygiene factors-factors that prove to be a source of dissatisfaction, such as: company policy and administration, technical supervision, salary, interpersonal relations, working conditions, job security and status.

Other aspects contained in job satisfaction according to Robbins (2006) are:

1. Mentally challenging work

Employees tend to like jobs that give them the opportunity to use their skills and abilities and offer assignments, freedom and feedback. These characteristics make work mentally challenging. A job that is too less challenging creates boredom, but too much challenging creates frustration and feelings of failure. In conditions of moderate challenges, most employees will experience pleasure and satisfaction.

\section{Fair rewards}

Employees want a wage system and promotion policies that they perceive are fair to their expectations. When wages are seen as fair based on job demands, individual skill levels and community wage standards, satisfaction is likely to result. Of course, not everyone is after money. Many people are willing to accept either less money to work in a more desirable location or in a job that is less demanding or has more flexibility in their job. But the key to the relationship between wages and satisfaction is not the absolute amount paid, the more important is the perception of fairness. Similarly, employees are seeking to gain more promotional policies and practices, and an improved social status. Therefore, individuals who perceive that promotional decisions are made in a fair manner are likely to experience satisfaction from their jobs. 


\section{Supporting working conditions}

Employees care about the work environment both for personal comfort and to make it easier to do assignments. Studies explain that employees prefer physical surroundings that are not dangerous or inconvenient. Temperature, light, noise, and other environmental factors should not be extreme (too much or too little).

\section{Supportive co-workers}

People get more than just money or tangible performance from work. For most employees, work also fills the need for social interaction. Therefore, it is not surprising that having friendly and supportive co-workers leads to increased job satisfaction. The behavior of one's superior is also a major determinant of satisfaction. In general, studies have found that employee satisfaction is enhanced when direct supervisors are friendly and understanding, offer praise for good performance, listen to employees' opinions, and show a personal interest in them.

5. Personality suitability for work

Basically, people whose personality type is in accordance with the job they choose should find that they have the right talents and abilities to meet the demands of their job. Thus, they will be more likely to be successful at the job, and because of this success, they will have a high satisfaction from their work. An understanding of job satisfaction can be realized if the analysis of job satisfaction is related to performance, level of absenteeism, desire to move, age, position and the size of the organization (Siagian, 2006).

\section{Methodology}

The population in this study were all 58 employees of the Faculty of Islamic Economics and Business UIN Walisongo Semarang. Samples taken were all employees, that were 58 employees. Data collection was carried out using a questionnaire by giving or distributing a list of questions to respondents. Each respondent was asked for his opinion by providing answers to the questions posed. The data were collected using a questionnaire by asking questions to get data about the indicators of the constructs being developed in this study. The statements in the questionnaire 
were made using a Likert scale of 1-5 to obtain discrete numerical data and were given a score or value.

This research used quantitative analysis. Respondents' perceptions were qualitative data that were measured on a scale so that the results were in the form of numbers. Furthermore, the numbers or scores were processed by statistical methods. This measurement method was to simplify the data analysis process. The research model used in this research was a panel data regression analysis model, and to test the proposed hypothesis, a path analysis technique was used.

\section{Results and discussion}

Test was conducted to test whether a construct had unidimensionality or whether the indicators used could confirm a construct or a variable. Validity test was done by calculating $r$ count with $r$ table. From the calculation results with regard to the value of $r$ count on testing the validity, the data were obtained as presented in Table 2.

Based on the table below, it is known that the value of $r$ count on each indicator is $>r$ table so that it can be concluded that the data used in this study is valid.

Table 2. Results of validity test

\begin{tabular}{llllll}
\hline No & Variable & Indicator & $\mathbf{r}_{\text {count }}$ & $\mathbf{r}_{\text {table }}$ & Specification \\
\hline 1 & Performance & P1 & 0.715 & 0.361 & Valid \\
& & P2 & 0.582 & 0.361 & Valid \\
& & P3 & 0.666 & 0.361 & Valid \\
& P4 & 0.538 & 0.361 & Valid \\
& & P5 & 1.343 & 0.361 & Valid \\
& & P6 & 0.672 & 0.361 & Valid \\
& \multirow{4}{*}{ Job Satisfaction } & P1 & 0,800 & 0,361 & Valid \\
& & P2 & 0.565 & 0.361 & Valid \\
& & P3 & 0.872 & 0.361 & Valid \\
& & P4 & 0,795 & 0,361 & Valid \\
& & P5 & 0,862 & 0,361 & Valid \\
& Work Motivation & P1 & 0.382 & 0.361 & Valid \\
& P2 & 0.378 & 0.361 & Valid \\
& & P3 & 0.432 & 0.361 & Valid \\
& P4 & 1.155 & 0.361 & Valid \\
& & P5 & 0.898 & 0.361 & Valid \\
\hline
\end{tabular}


Table 3. Results of reliability test

\begin{tabular}{llll}
\hline No & Variable & $\mathbf{r}_{11}$ & $\mathbf{r}_{\text {Table }}$ \\
\hline 1 & Performance & 1,007 & 0,361 \\
2 & Job Satisfaction & 0.865 & 0.361 \\
3 & Work Motivation & 1.027 & 0.361 \\
\hline
\end{tabular}

\section{JIEMB | 42 Reliability test}

Testing in this study was conducted by comparing $r_{11}$ with $r$ table. From the calculation results with regard to the value of $r_{11}$ on testing the reliability, the data were obtained as shown in Table 3. Based on the results of the reliability test presented in Table 3, each research variable has $r_{11}$ more than 0.361 . so it can be concluded that all research variables are reliable.

Based on the results of the reliability test presented in Table 3, each research variable has $r_{11}$ more than 0.361 . So it can be concluded that all research variables are reliable.

The coefficient of determination has a function to explain the extent to which the ability of work motivation and job satisfaction has on employee performance by looking at the $\mathrm{R}$ square. The results of the coefficient of determination can be seen in Table 4 .

Results of analysis of data on the performance of employees show that $R^{2}$ of 0.659 , thus showing that motivation and job satisfaction on the performance of $65.9 \%$ and the remaining $34.1 \%$ is influenced by other factors not discussed in this study.

\section{T-test (Partial)}

This partial test can be seen from the $t$ test. If the obtained $p$ value $<0.05$, Ho is rejected, which means that there is a significant effect. The partial test results can be seen in Table 5 .

In table 5, equation I shows a constant value of 6.449. From the above test, coefficient obtained for work motivation is at .789 witht $=11.313$ with $\mathrm{p}$-value $=0.000<0.05$ so that $\mathrm{Ha}$ accepted which

Table 4. Test of the Coefficient of Determination

\begin{tabular}{|c|c|c|c|c|c|}
\hline \multirow[b]{2}{*}{ Model } & \multirow[b]{2}{*}{$\mathbf{R}$} & \multirow[b]{2}{*}{ R Square } & \multicolumn{3}{|c|}{ Std. Error of the } \\
\hline & & & Adjusted R Square & Estimate & Durbin-Watson \\
\hline 1 & $.812^{\mathrm{a}}$ & .659 & .646 & 1.17982 & 1,989 \\
\hline \multicolumn{6}{|c|}{ a. Predictors: (Constant), Satisfaction, Motivation } \\
\hline \multicolumn{6}{|c|}{ b. Dependent Variable: Performance } \\
\hline
\end{tabular}


Table 5. T-test Results of Equation I

\begin{tabular}{|c|c|c|c|c|c|c|}
\hline \multirow{2}{*}{ Model } & & \multicolumn{2}{|c|}{ Unstandardized Coefficients } & \multirow{2}{*}{$\begin{array}{l}\text { Standardized } \\
\text { Coefficients } \\
\text { Beta }\end{array}$} & \multirow{2}{*}{$\mathbf{T}$} & \multirow{2}{*}{ Sig. } \\
\hline & & B & Std. Error & & & \\
\hline \multirow[t]{2}{*}{1} & (Constant) & 6,449 & 1,249 & & 5,165 & .000 \\
\hline & Motivation & .789 & .070 & .834 & 11,313 & .000 \\
\hline
\end{tabular}

means the hypothesis that there is an effect of motivation to work on job satisfaction is accepted.

In Table 5, equation I shows a constant value of 6.449. From the above test, coefficient obtained for work motivation is at .789 witht $=11.313$ with $p$-value $=0.000<0.05$ so that $\mathrm{Ha}$ accepted which means the hypothesis that there is an effect of motivation to work on job satisfaction is accepted.

In Table 5, equation I shows a constant value of 6.449. From the above test, coefficient obtained for work motivation is at .789 witht $=11.313$ with $p$-value $=0.000<0.05$ so that $\mathrm{Ha}$ accepted which means the hypothesis that there is an effect of motivation to work on job satisfaction is accepted. The coefficient value for the work motivation variable is positive, which means that the better the work motivation, the higher the job satisfaction.

In equation II, the constant value is 6,014. From the above test, the coefficient for work motivation variable is 0.303 with tcount $=$ 2.221 with $\mathrm{p}$-value $=0.030<0.05$ so that $\mathrm{Ha}$ is accepted, which means that the hypothesis that there is an effect of work motivation on performance is accepted. The coefficient value for the work motivation variable is positive, which means that the better the work motivation, the higher the employee performance.

The test results for the job satisfaction variable obtained a coefficient of 0.533 with tcount $=3.700$ with $p$-value $=0.001$, because

Table 6. Coefficients of Equation II

\begin{tabular}{cllllll}
\hline \multirow{2}{*}{ Model } & & \multicolumn{2}{c}{$\begin{array}{c}\text { Unstandardized } \\
\text { Coefficients }\end{array}$} & $\begin{array}{c}\text { Standardized } \\
\text { Coefficients }\end{array}$ & T & \multirow{2}{*}{ Sig. } \\
\cline { 3 - 6 } & & B & Std. Error & Beta & & \\
\hline \multirow{2}{*}{1} & (Constant) & 6,014 & 1,635 & & 3,677 & .001 \\
& Motivation & .303 & .136 & .317 & 2,221 & .030 \\
& Satisfaction & .533 & .144 & .528 & 3,700 & .001 \\
\multicolumn{2}{c}{ a. Dependent Variable: Performance } & & & \\
\hline
\end{tabular}


p-value $0.001<0.05$ so that $\mathrm{Ha}$ is accepted, which means that the hypothesis that there is an influence of job satisfaction on performance is accepted.

The test results for the job satisfaction variable obtained a JIEMB | 44 coefficient of 0.533 with tcount $=3.700$ with $p$-value $=0.001$, because p-value $0.001<0.05$ so that $\mathrm{Ha}$ is accepted, which means that the hypothesis that there is an influence of job satisfaction on performance is accepted. The coefficient value for the job satisfaction variable is positive, which means that the better the job satisfaction, the higher the employee performance decision. From the results of the above analysis, the following regression model is obtained:

$$
\begin{aligned}
& Y=6.449+0.789 X \\
& Z=6.014+0.303 X+0.533 Y \\
& \text { With }
\end{aligned}
$$

Z: Performance

$X$ : Work Motivation

$Y$ : Job Satisfaction

The regression model above shows that every $1 \%$ increase in work motivation will be followed by an increase in performance of $0.303 \%$ and every $1 \%$ increase in job satisfaction will be followed by an increase in performance of $0.533 \%$.

\section{Intervening test}

The results of the path analysis are described in Figure 1. Based on the results of the path analysis, work motivation has a direct effect on employee performance, while work motivation has an indirect effect on performance through job satisfaction

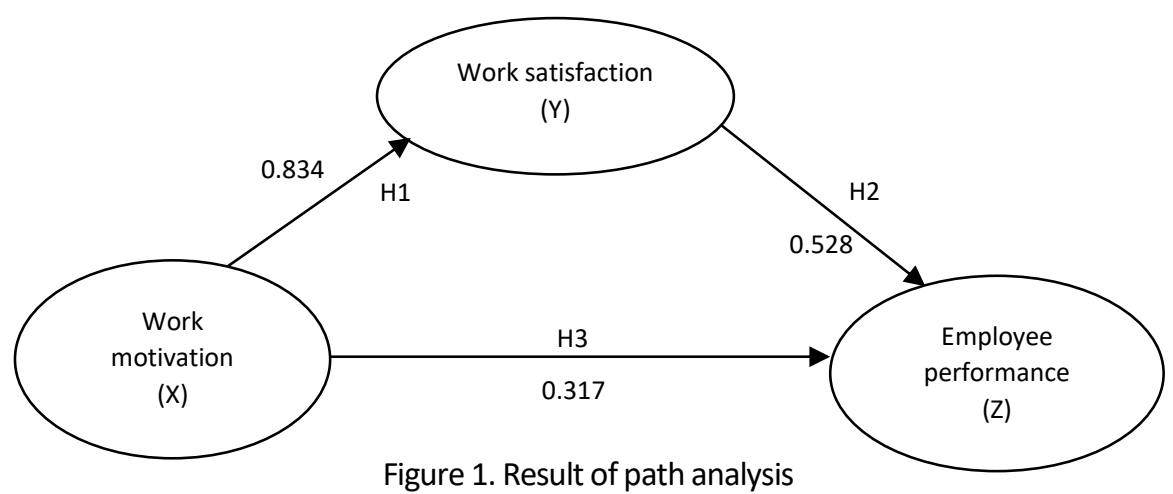


Based on the results of the path analysis, work motivation has a direct effect on employee performance, while work motivation has an indirect effect on performance through job satisfaction (intervening). The magnitude of the direct effect of work motivation is (0.317) while the magnitude of the indirect effect must be calculated by multiplying the indirect coefficient, that is $(0.834) \mathrm{x}$ $(0.528)=(0.440)$ or the total effect of work motivation on employee performance is $(0.317)+(0.834 \times 0.528)=(0.757)$.

\section{The effect of work motivation on job satisfaction}

Results of statistical tests that have been conducted show that there is an effect of work motivation on job satisfaction. The coefficient value is positive, indicating that work motivation has a positive effect on job satisfaction. The higher the work motivation, the higher the job satisfaction. The results of this study are in accordance with research conducted by Ningrum (2013) which states that work motivation has a positive and significant effect on job satisfaction.

\section{The effect of work motivation on performance}

Based on the results of this study it is stated that there is an influence of work motivation on performance. The coefficient value for the work motivation variable is positive, which means that the higher the work motivation, the higher the employee performance.

The results of this study are in accordance with research conducted by Ningrum (2013), Iswandani (2016), Rahman and Solikhah (2016), which state that work motivation has a positive and significant effect on performance.

\section{The effect of job satisfaction on performance}

Based on the research that has been done, it is concluded that job satisfaction has an effect on performance. The coefficient value for the job satisfaction variable is positive. This means that the higher the job satisfaction, the higher the employee performance.

The results of this study are in accordance with research conducted by Ningrum (2013), Dewi and Sutrischastini (2016), Rahman and Solikhah (2016), which state that job satisfaction has a positive and significant effect on performance. 
The effect of work motivation on performance with job satisfaction as

\section{an intervening variable}

Based on the comparison between the amount of the indirect effect (intervening) and the direct effect, it can be seen that the indirect effect is greater than the direct effect, that is $0.440>0.317$.

These results indicate that the job satisfaction variable can mediate the influence of motivation on employee performance is greater than the direct influence of motivation on employee performance. The results of this study are in accordance with research conducted by Ningrum (2013) which states that work motivation has an indirect effect on performance through job satisfaction (intervening).

\section{Conclusion}

Based on data analysis and discussion of research results, the following conclusions can be drawn. Work motivation variable has a positive and significant effect on job satisfaction at the Faculty of Islamic Economics and Business UIN Walisongo Semarang. Work motivation variable has a positive and significant effect on performance at the Faculty of Islamic Economics and Business UIN Walisongo Semarang.

Job satisfaction variable has a positive and significant effect on performance at the Faculty of Islamic Economics and Business UIN Walisongo Semarang. Based on the path analysis, it is found that motivation affects performance through job satisfaction. Therefore, it can be concluded that job satisfaction becomes the intervening variable between motivation towards performance in Faculty Economics and Islamic Business UIN Walisongo Semarang.

\section{Reference}

Alwiyah. (2016). Economica: Jurnal Pemikiran Dan Penelitian Ekonomi Islam. Economica: Jurnal Ekonomi Islam. Vol. 7. http://journal.walisongo.ac.id/index.php/economica/article/view/115 4/918.

Brahmasari, IA dan A. Suprayetno. (2008). "Pengaruh Motivasi Kerja, Kepemimpinan dan Budaya Organisasi terhadap Kepuasan Kerja Karyawan serta Dampaknya pada Kinerja Perusahaan (Studi kasus pada PT. Pei Hai International Wiratama Indonesia)" Jurnal Manajemen dan Kewirausahaan. Vol. 10, No. 2: 124-135. 
Dessler, G. (2000). Manajemen Sumber Daya Manusia. Edisi Terjemahan, Jakarta: PT. Prenhallindo.

Dewi, K., \& Sutrischastini, A. (2016). Pengaruh Motivasi Dan Gaya Kepemimpinan Terhadap Kinerja Karyawan Melalui Kepuasan Kerja Karyawan Sebagai Variabel Intervening Di Pd Bpr Bkk Wonosobo. Jurnal Riset Manajemen Sekolah Tinggi IImu Ekonomi Widya Wiwaha Program Magister Manajemen, 3(1), 61-77.

Herzberg, F. (2017). Motivation to work. Routledge.

Kreitner, Robert and Angelo Kinicki. (2005). Perilaku Organisasi. Buku 1, Edisi Kelima. Jakarta: Salemba Empat.

Koesmono, H. T. (2005). Pengaruh budaya organisasi terhadap motivasi dan kepuasan kerja serta kinerja karyawan pada sub sektor industri pengolahan kayu skala menengah di Jawa Timur. Jurnal manajemen dan kewirausahaan, 7(2), 171-188.

Listianto, Tony dan Bambang Setiaji. (2007). Pengaruh Motivasi, Kepuasan dan Disiplin Kerja terhadap Kinerja Karyawan (Studi Kasus di Lingkungan Pegawai Kantor PDAM Kota Surakarta).

Locke, E. A. (1970). Job satisfaction and job performance: A theoretical analysis. Organizational behavior and human performance, 5(5), 484-500.

Mangkunegara, AA Anwar Prabu. (2001). "Manajemen Sumber Daya Manusia Perusahaan". Bandung: PT Remaja Rosdakarya.

Ningrum, N.G,. (2013)." Analisis Pengaruh Motivasi Kerja terhadap Kinerja dengan Kepuasan Kerja Sebagai Variabel Intervening". Master Thesis, Diponegoro University.

Prasetyo, Edhi,. \& Wahyuddin. (2003). Pengaruh Motivasi dan Kepuasan Kerja terhadap Produktivitas Kerja Karyawan Riyadi Palace Hotel di Surakarta. Thesis (unpublished). Program Pascasarjana Universitas Muhammadiyah Surakarta. Solo.

Rahman, T., \& Solikhah, S. (2016). Analisis Pengaruh Rotasi Kerja, Motivasi Kerja dan Kepuasan Kerja terhadap Kinerja Karyawan di Lembaga Keuangan Mikro Syariah. Muqtasid: Jurnal Ekonomi dan Perbankan Syariah, 7(2), 23-49.

Robbins. (2006). Perilaku Organisasi. Jakarta: Salemba Empat.

Siagian, S.P. (2008). Manajemen Sumber Daya Manusia. Jakarta: PT Bumi Aksara.

Wanous, J. P., \& Lawler, E. E. (1972). Measurement and meaning of job satisfaction. Journal of applied psychology, 56(2), 95. 
Nurudin

JIEMB | 48

Journal of Islamic Economics, Management, and Business-Vol 2. No.1 (2020 